\title{
Work Satisfaction Antecedents and Consequences: An Analysis of Transformational Leadership Style, Communication and Performance of the Nurses (Study on the Hospital Nurses in Indonesia)
}

\author{
Sari Dewi Rosady ${ }^{1}$, Tantri Yanuar Rahmat $\operatorname{Syah}^{2}$ \\ Esa Unggul University
}

\begin{abstract}
Related with the success of a hospital, the best performance of the nurses is the key to success. Success in carrying out the work and the formation of a comfortable environment due to the influence of communication and transformational leadership style can make the nurses achieve job satisfaction. Job satisfaction that arises will certainly have an impact on improving the performance of nurses in the hospital, it is expected that problems that occur related to the low performance of the nurses can be resolved properly. The purpose of this study is to determine the effect of transformational leadership style and communication on the performance of nurses with mediation of nurses' job satisfaction. Respondents used were 115. Data were analyzed using Structural Equation Model (SEM). The results showed that the transformational leadership style had an effect on the nurses' job satisfaction, the transformational leadership style had an effect on the nurses' performance, the communication did not affect the nurses' job satisfaction, the communication did not affect the nurses' performance and the nurses' job satisfaction had no effect on the nurses' performance.
\end{abstract}

Keywords: Transformational leadership style, communication, performance, satisfaction, hospital, nurse

\section{INTRODUCTION}

One way to keep company in the increasingly tight competition is by improving the performance of human resources. Improved employee performance is also influenced by the leadership style applied by the company, such as transformational leadership style. A good transformational leadership style can improve employee job satisfaction that can lead to good performance. Not only the style of transformational leadership that can improve employee performance in the company. Communication within the organization is an important factor that should be given more attention by the company. To achieve the goals of the company, then the communication relationship between superiors and subordinates must be established effectively in order to happen a good cooperation.

Bushra, Usman and Naveed (2011) research aims to determine the effect of transformational leadership style on employee job satisfaction and organizational commitment to the banking sector in Pakistan. The research method used was regression analysis and the research result showed that transformational leadership style influences job satisfaction and transformational leadership style influences organizational commitment. Paracha, Qamar, Mirza, Hassan and Waqas (2012) analyzed the influence of transformational leadership style on employee performance mediated by job satisfaction in the education industry in Pakistan. The result of the analysis concluded that transformational leadership style had an effect on employee performance and job satisfaction to mediate the transformational leadership style on employee performance. The research by Tourani and Rast (2012) discussed the effect of communication on employees' job satisfaction on the aviation industry in Iran and the results of the study concluded that communication had an effect on the employees' job satisfaction. Epure, Ionescu and Nancu (2013) examined the effect of communication on employees' job satisfaction at the company in Rumanian, the result of their research showed the communication effect on employees' job satisfaction.

Ahmad, Adi, Noor, Rahman and Yushuang (2013) examined the transformational leadership style of the nurses' job satisfaction and the result of the study concluded that the transformational leadership style had an effect on the nurses' job satisfaction. While Femi (2014) analyzed the impact of communication on employee performance in companies in Nigeria. The result showed the communication has an effect on the performance of employees. Advani and Abbas (2015) research discussed the impact of transformational leadership styles on employee performance in the banking sector in Pakistan. Method. The result concluded that transformational leadership style had an effect on employee performance. 


\title{
International Advanced Research Journal in Science, Engineering and Technology
}

\author{
Vol. 5, Issue 9, September 2018
}

Researchers Awaludin, Adam and Mahrani (2016) aimed to determine the effect of job satisfaction towards employee performance. The result concluded that job satisfaction affected on employee performance. Temitope, Oluwatomilola, Olanrewaju and Airekun (2016) tested the relationship between communication and employee performance in private organizations. The conclusion of their research showed that communication affected employee performance through organizational commitment and productivity. While Naeem and Khanzada (2018) conducted a research to know the influence of transformational leadership on employee performance which was mediated by employee job satisfaction in health industry, and the result showed that the transformational leadership had an influence on job satisfaction, transformational leadership had an influence to employee performance, job satisfaction had an influence to employee performance and satisfaction work mediated transformational leadership on employee performance.

As well as in the health industry, such as in RSIA Family North Jakarta. As a hospital it certainly has a focus on patient health services, which will indirectly lead to the performance of nurses at RSIA Family. The performance of the nurses is very important in the effort to develop and improve the quality of RSIA Family to the public. The success of nurses' performance depends on how the nurses provide quality nursing care to the patient. One indicator to assess the effectiveness, efficiency and quality of hospital services is the number of BOR (Bed Occupancy Ratio). According to the Health Service of the Republic of Indonesia/DEPKES RI (2005), BOR is the percentage of bed usage in a certain time unit that describes the low level of bed utilization in a hospital. The ideal BOR parameter value is $60 \%-85 \%$ (DEPKES RI). From the data obtained in the last 3 (three) years period showed that the BOR rate in RSIA Family was still low or below MOH standard.

With the low BOR and declining trend in the last three years, the RSIA Family as a health service unit is required to continually develop and improve the performance of the nurses, especially in the inpatient section. Increased inpatient room is influenced by the performance of nurses which is the spearhead of care in the treatment room. The leaders of RSIA must be able to build awareness of nurses and encourage them to go beyond their personal interests in order to achieve group interest, hospital and community progress. It is expected that the motivation given by the leaders can realize the responsibility for the duties of the nurses. Nurses will be encouraged to do their best to achieve the goals to be achieved. Success in running their work and the formation of a comfortable environment resulting from communication and transformational leadership style can make the nurses achieve job satisfaction. Job satisfaction that arises will certainly have an impact on improving the performance of nurses at RSIA, it is expected that problems related to the low number of BOR can be resolved well. From the description of the above background, the goal to be achieved in this research is to provide an explanation of transformational leadership style, communication and job satisfaction of nurses on the performance of nurses. (A study on Nurses of RSIA Family, North Jakarta).

\section{LITERATURE REVIEW}

Transformational Leadership Style: According to Northouse (2013) transformational leadership is a leadership that increases employees' motivation, satisfies the needs of employees and treats them as whole human beings. Rivai, Bachtiar and Amar (2014) define transformational leadership as a type of leadership that guides or motivates their followers in the direction of enforced goals by clarifying roles and task demands. Meanwhile, according to Avolio and Bass (2004), transformational leadership style can be measured by four dimensions, such as: idealized influence, inspirational motivation, intellectual stimulation, and individual consideration.

Communication: Communication is the process by which a person seeks to provide understanding by way of message transfer (Stoner, 2006). Communication within the organization is an important factor that should be given more attention by the company. Wahidah (2011) defines communication as the relationship of contact between and intrahumans, both individuals and groups. Pace and Faules (2010) stated that communication can be measured by using dimensions that include: downward communication, upward communication, horizontal communication, cross-channel communication, and personal or informal communication.

Job Satisfaction: According to Kreitner and Kinicki (2014) job satisfaction is an effectiveness or an emotional response to various aspects of work. Davis (2011) describes job satisfaction as a set of employee feelings about whether or not their work is fun. Job satisfaction can be measured by the employment dimensions: salary, opportunity for promotion, supervision and co-workers (Munadar, Smith, Kendall and Hulin, 2004).

Performance: Mangkunegara (2009) defines the performance of employees as a result of work in quality and quantity achieved by an employee in performing their duties in accordance with the responsibilities given to them. Rivai and Sagala (2013) stated that performance is a function of motivation and ability. In order to complete a task or job a person should have a degree of willingness and a certain level of ability. Mitchel (1978) said performance can be measured using several aspects, including quality of work, punctuality, initiative, and good communication and skills. 


\title{
International Advanced Research Journal in Science, Engineering and Technology
}

\author{
Vol. 5, Issue 9, September 2018
}

III. HYPOTHESES

Leaders become one of the decisive factors in achieving the vision and mission of the company (Pandey, 2010), because leaders become an important element in the success of an organization. Through a transformational leadership style a leader is able to be fair and direct his goals and expectations clearly to the success of the organization. Job satisfaction of the nurses will appear if the expectations in accordance with reality that the nurses managed to prove themselves, that their efforts can bring progress to the hospital. In this case the transformational leadership style is able to encourage nurses to go beyond their personal interests in order to achieve common interests. Ostroff (1992) in Darwito (2008) said that the high level of job satisfaction depends on the goodness and attitude of the bosses. The nurses' job satisfaction is related to the nurses' expectation toward the boss, co-workers and the job itself. This is in accordance with Bushra, et al's research (2011); Paracha, et al. (2012); Ahmad, et al. (2013); Naeem and Khanzada (2018) who concluded transformational leadership style affected the job satisfaction. Based on the literature above the following hypothesis can be submitted:

\section{$\mathrm{H}_{1}$ : Good transformational leadership style will increase nurses' job satisfaction.}

Leadership toward nurses has a major impact on nurse performance to achieve hospital goals. The transformational leadership style can direct employees to the goals to be achieved (Pradana, Sunuharyo and Hamid., 2013). In addition, the transformational leadership style has provided optimistic views that encourage employees to be motivated in working to produce good performance (Davis, 2011). The best performance performed by the nurses will bring its own benefits for the hospital. Hospital will be able to survive in a competitive environment in an unstable business environment. This is consistent with Paracha, et al's study (2012); Naeem and Khanzada (2018); Advani and Abbas (2015) who concluded the transformational leadership style affected the performance of employees. From the literature above, then the hypothesis that can be filed is as follows:

\section{$\mathrm{H}_{2}$ : Good transformational leadership style will improve nurses' performance.}

To be able to generate job satisfaction, it is influenced by several factors. One of which lies in the quality of human resources and communications (Goetsch and Davis, 2013), where communication is an important part in the environment of organizational life (Hariandja, 2009). Through communication, the nurses know new information about what is allowed and should not be done, the culture of the work environment and changes to the target tasks that must be achieved every day. If all policies can be heard and delivered properly, it is expected that the result of nurses' performance can be in accordance with the standards of the hospital. Nurses will get the best assessment of their performance so that it can lead to nurses' job satisfaction. This is in accordance with the research conducted by Tourani and Rast (2012); Epure, et al. (2013) which mentioned about the effect of communication on job satisfaction. From the literature above, then the hypothesis that can be filed is:

\section{$\mathrm{H}_{3}$ : Good communication will increase nurses' job satisfaction.}

Robbins (2013) says communication helps to motivate development by telling employees what to do, how well they work, and what can be done to improve sub-standard performance. Well established cooperation on the nurses are able to apply or follow the hospital program strategies applied. The success of each nurse in executing the strategy program was implemented by the leadership, it can be seen from the performance shown. If the performance of the nurses has increased, then it can be said that the communication goes well. On the contrary, if the performance decreases, it can be said that communication is not going well from the leader to his subordinates or fellow co-workers. This is consistent with Femi (2014) and Temitope, et al. (2016) which concluded the communication effect on employees' performance. From the literature above, the hypothesis that can be filed is:

\section{$\mathrm{H}_{4}$ : Good communication will improve nurses' performance.}

All activities undertaken by a hospital will ultimately lead to how to improve the performance of nurses so that patients feel comfortable, satisfied and loyal. In order to improve the performance of the nurses, the leaders must be able to see the needs and the nurses at work place so as to bring job satisfaction for the nurses. All applicable policies must be strict, fair and real. If this goes well, then the working environment can be created comfortably, pleasantly and the nurses will be satisfied. This is because the nurses' job satisfaction is related to the expectation of the nurses to the boss, co-workers and the job itself. This is consistent with the Paracha, et al.'s study (2012); Awaludin, et al. (2016); Naeem and Khanzada (2018) who concluded that job satisfaction affected the performance of employees. From the literature above, the hypothesis that can be filed is:

$H_{5}$ : High nurses' job satisfaction will improve nurses' performance.

\section{RESEARCH METHOD}

This research was conducted on the nurses of RSIA Family, North Jakarta, Indonesia. The aspects studied were transformational leadership style, communication, nurses' job satisfaction and nurses' performance. The study was conducted in March 2018 by survey method. This research is descriptive. The data were collected by spreading 


\title{
International Advanced Research Journal in Science, Engineering and Technology
}

\author{
Vol. 5, Issue 9, September 2018
}

questionnaires to RSIA Family Nurses in North Jakarta, Indonesia. Methods of data analysis in this study used Structural Equation Modeling (SEM). Hair, Anderson, Tatham and Black (2008) stated that the respondents should be at least 5 times the number of questionnaires so that in this study the number of operational questionnaires used was as much as thirty three, so that the sample taken in this study was 115 (23 x 5) respondents, with five variables of leadership style transformational, communication, job satisfaction, and performance. The data has been collected and then experienced Likert scale measurement with a scale of one to five (Sugiyono, 2012). The results of the analysis were then interpreted and the final step was to conclude and give a suggestion.

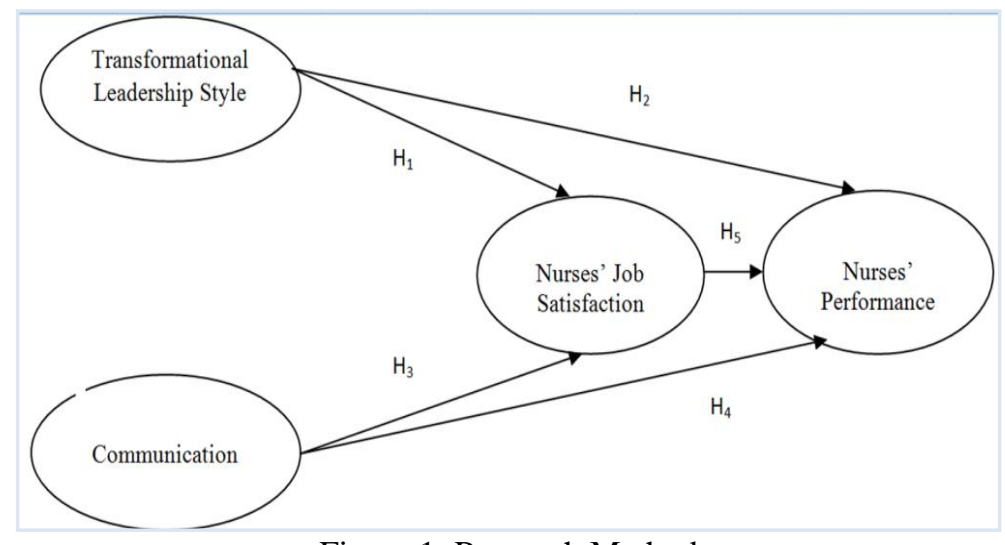

Figure 1: Research Method

Measurement: In this research, there were three independent variables, i.e. transformational leadership style, communication, nurses' job satisfaction and one dependent variable, i.e. nurse performance. Measurement of transformational leadership style variable used the theory of Avolio and Bass (2004), the measurement of communication variable used theory of Pace and Faulus (2010), measurement of job satisfaction variable used theory of Munadar, Smith, Kendall and Hulin (2004) and the measurement of performance variable used the theory of Mitchel (1978).

This research used confirmatory factor analysis, by doing validity test by looking at Kaiser-Msyer-Olkin measure of sampling (KMO) and measure of sampling adequacy (MSA). In this test the value obtained must be greater than 0.500 which means that factor analysis is appropriate for use, and can be further processed (Doll, Xia and Torkzadeh, 1994). The scale of transformational leadership style consisted of 16 questions and they were all valid because of its value (MSA > 0.500), the communication scale consisted of 9 questions and they were all valid because of its value (MSA > $0.500)$, job satisfaction scale consisted of 31 questions and there were 8 invalid questions because the component matrices were more than 1 (one), the invalid questions were on KK5 (0.460), KK16 (0.604), KK13 (0.420), KK10 (0.805), KK1 (0.788), KK8 (0.819), KK26 (0.474) dan KK25 (0.806). While the performance scale consisted of 15 questions and were not all valid because their values (MSA < 0.500) were on Ki5 (0.264) dan Ki12 (0.490). Reliability test was conducted with the value of alpha cronbach $>0.5$ which meant reliable (Sugiyono, 2012), so it can be said that the indicators of all variables can be said trusted as the means of data collection in this research.

\section{RESULTS AND DISCUSSION}

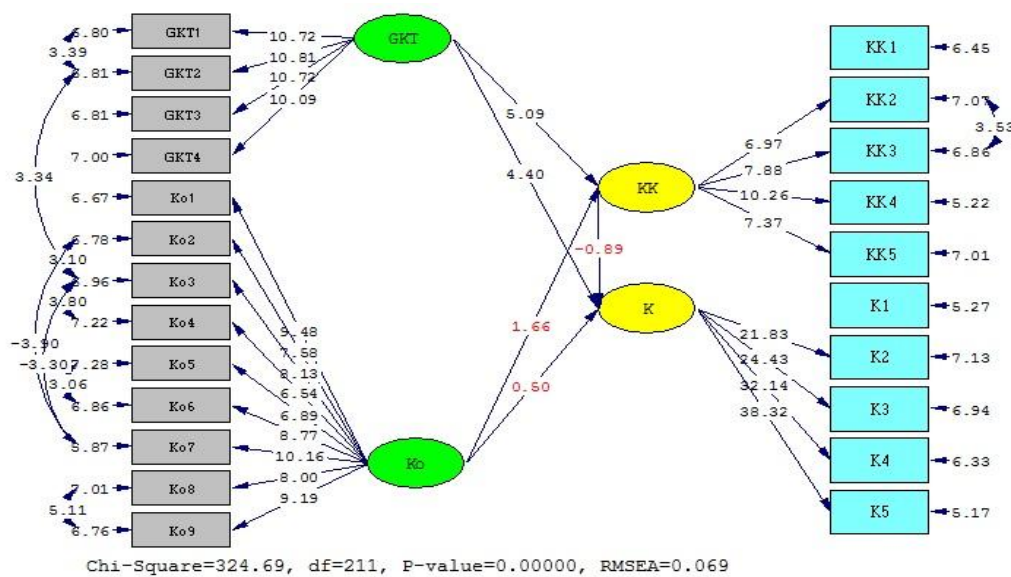

Figure 2: Path Diagram t-value 


\title{
International Advanced Research Journal in Science, Engineering and Technology
}

\author{
Vol. 5, Issue 9, September 2018
}

Analysis of all tests almost showed good matches, including Chi Square, RMSEA, ECVI, AIC, CAIC and Fit Index. There was a poor fit in Critical $\mathrm{N}$ and marginal fit on Goodness of Fit. Furthermore, this research produced the path diagram as follows:

Based on Figure 2 Path Diagram T-Value which is hypotheses in this study, they are presented in the table of hypotheses testing as follows:

Table 2: Hypotheses Testing of Research Model

\begin{tabular}{|l|l|l|l|}
\hline Hypothesis & Hypothesis statement & T-Value & Remark \\
\hline $\mathrm{H}_{1}$ & $\begin{array}{l}\text { Good transformational leadership style will } \\
\text { increase nurses' job satisfaction. }\end{array}$ & 5.09 & $\begin{array}{l}\text { Data support } \\
\text { hypothesis }\end{array}$ \\
\hline $\mathrm{H}_{2}$ & $\begin{array}{l}\text { Good transformational leadership style will } \\
\text { improve nurses' performance. }\end{array}$ & 4.40 & $\begin{array}{l}\text { Data support } \\
\text { hypothesis }\end{array}$ \\
\hline $\mathrm{H}_{3}$ & $\begin{array}{l}\text { Good communication will increase nurses' } \\
\text { job satisfaction. }\end{array}$ & 1.66 & $\begin{array}{l}\text { Data do not support } \\
\text { hypothesis }\end{array}$ \\
\hline $\mathrm{H}_{4}$ & $\begin{array}{l}\text { Good communication will improve nurses' } \\
\text { performance. }\end{array}$ & 0.50 & $\begin{array}{l}\text { Data do not support } \\
\text { hypothesis }\end{array}$ \\
\hline $\mathrm{H}_{5}$ & $\begin{array}{l}\text { High nurses' job satisfaction will improve } \\
\text { nurses' performance. }\end{array}$ & -0.89 & $\begin{array}{l}\text { Data do not support } \\
\text { hypothesis }\end{array}$ \\
\hline
\end{tabular}

Discussion: The result of the first hypothesis testing (H1) found the result of analysis supported H1 hypothesis that good leadership style will increase nurses' job satisfaction of 5.09. The test results showed that the transformational leadership style affected the satisfaction of nurses work at RSIA Family in North Jakarta. To become the leading hospital, the performance of human resources becomes one of the most important aspects that need attention. The results of this study confirmed the results of Bushra, et al. (2011); Paracha, et al. (2012); Ahmad, et al. (2013); Naeem and Khanzada (2018) who concluded transformational leadership style affected the job satisfaction.

The result of the second hypothesis testing (H2) found that the result of analysis supported $\mathrm{H} 2$ hypothesis that good transformational leadership style will improve nurses' performance which was equal to 4.40 . This indicates that the improved transformational leadership style applied to RSIA Family North Jakarta can improve the performance of the nurses. Through the transformational leadership style, leaders are able to provide things that can improve the motivation of the nurses and lead them to improve their performances. The results of this study corroborated the results of Paracha, et al. (2012); Naeem and Khanzada (2018); Advani and Abbas (2015) who concluded that the transformational leadership style affected the performance of employees.

In the result of the third hypothesis testing (H3), it was found that the result of analysis did not support H3 hypothesis that good communication does not increase nurses' job satisfaction which was equal to 1.66. The results of this test showed that communication does not affect the satisfaction of nurses working in RSIA Family North Jakarta. The result of this study is not in line with the previous researches by Tourani and Rast (2012); Epure, et al. (2013) which mentioned about the communication effect on job satisfaction. But it supported the results of the research conducted by Yuseph (2012) which concluded the communication has no effect on job satisfaction at the company psychological contract.

The result of testing of fourth hypothesis (H4) found that the result of analysis does not support hypothesis H4 that is communication does not improve nurses' performance which was equal to 0.50 . The result of this test showed that the communication does not affect the performance of Nurses of RSIA Family. Communication within RSIA FAmily hospital has not fully worked out. The result of this study is not in line with the researches by Femi (2014) and Temitope, et al. (2016) who said the communication affected the performance of employees. However, the research result supported Lalamentik, Kingdangen and Lengkong (2017) that the communication does not affect the performance of employees in the State Wealth Service Office and Auction in Manado.

The result of testing of fifth hypothesis (H5) found that the analysis does not support hypothesis H5 that job satisfaction does not improve nurses' performance which was equal to -0.89 . The result of this test showed that the job satisfaction does not affect the performance of nurses of RSIA Family North Jakarta. The result of this research supported the researches of Masihabadi, Rajaei, Koloukhi, and Parsian (2015); Subekti and Setyadi (2016) who concluded that job satisfaction has no effect on performance. But it was not in line with Paracha, et al. (2012); Awaludin, et al. (2016); Naeem and Khanzada (2018) who said job satisfaction affected the performance of employees. 


\title{
International Advanced Research Journal in Science, Engineering and Technology
}

\author{
Vol. 5, Issue 9, September 2018
}

\section{MANAGERIAL IMPLICATIONS}

Managerial implications to improve the transformational leadership style towards job satisfaction and performance that can be proposed that are by looking at the dimensions used in this study. The first dimension is idealized influence, which describes the leader as an example of a strong role for his followers. Leaders must be able to show leadership attitude so they will be well respected by the nurses. The nurse will be reluctant, respect for their leaders. The prevailing cultural values in the work environment, will not hesitate to run. This is because the nurses believes in their leadership, that whatever the leaders do will bring good impact for RSIA Family progress. Furthermore, the implication for the second dimension, i.e. inspirational motivation describes leaders who discuss high expectations to followers and motivate them through their vision. In this case the leaders can make several approaches to the nurses. Leaders can hold family gathering to increase intimacy, enhance cooperation among colleagues. This situation is expected to provide leadership opportunities in achieving their goals and objectives. Leaders can instill an optimistic picture to the nurses of what the hospital vision will achieve.

Implication of the third dimension of intellectual stimulation which describes leaders who support followers to try new approaches and develop innovative ways. Leaders are required to be responsive and adaptive, always follow and adjust to environmental circumstances. The management of the hospital decided to create a new policy or program to adapt to global change. The existence of a new policy that must be made to think about the position of the welfare of its human resources, the leaders must realize that the success of the improvement initiatives depends on the participation and contribution of the nurses. The implication for the fourth dimension, i.e. individual consideration describes that the leaders should build a supportive climate by listening to what the followers need and being a mentor to followers to make them more actualized. The success of a leader can be seen from how he/she directs his/her subordinates. Success in a nurse's work does not escape from the direction of the leader and the leadership can work with HRD to find out the performance of the nurses, whether it decreases or increases, and the constraints experienced by the nurses at work.

\section{CONCLUSION}

Conclusion: The results that can be concluded from this research: (1) there is an influence of leadership style on nurses' job satisfaction at RSIA Family, North Jakarta, it can be said that good transformational leadership style will increase nurses' job satisfaction; (2) there is an influence of transformational leadership style on nurses' performance at RSIA Family hospital, North Jakarta, it can be said that good transformational leadership style will improve nurses' performance at RSIA Family hospital; (3) there is no communication effect on nurses' job satisfaction at RSIA Family, North Jakarta; (4) there is no communication effect on nurses' performance at RSIA Family hospital, North Jakarta; (5) there is no influence between job satisfaction on nurses' performance of RSIA Family, North Jakarta.

Limitations of Research: Our study has several limitations that can be considered for further research. Limitations of this study include: (1) this study was conducted at one hospital namely RSIA Family, North Jakarta; (2) the subjects of this study were limited to the nurses of RSIA Family, North Jakarta; (3) this study dealt only with transformational leadership style, communication, nurses' job satisfaction, and nurses' performance; (4) there was a possibility that the respondents did not fill in completely or just fill in on the expected ideal conditions and not based on the actual conditions that were occurring.

Suggestions for Further Research: Future research development can add other variables that affect nurses' job satisfaction and nurses' performance. Further research is expected to be conducted by extending the scope of the study, for example by using samples not only from hospital nurses and increasing the number of samples studied.

\section{REFERENCES}

[1]. Advani, S., and Abbas, Z. 2015. Impact of Transformational and Transactional Leadership Styles on Employees Performance of Banking Sector in Pakistan. Global Journal of Management and Business Research: Administration and Management. Vol 15 Issue 5.

[2]. Aqmarina, N.F., Utami, H.N., dan Prasetya, A. 2016. Pengaruh Kepemimpinan Transformasional dan Traksaksional terhadap Kepuasan Kerja dan Kinerja Karyawan (Studi pada Karyawan Hotel Gajahmada Graha Malang). Jurnal Administrasi Bisnis (JAB). Vol. 35 No. 2.

[3]. Avolio, B.J., and Bass, B.M. 2004. Multifactor leadership questionnaire: Manual and Sampler set. 3rd edition. Redwood City Mind Garden, Inc.

[4]. Awaludin, I., Adam, L.O., and Mahrani, S.W. 2016. The Effect of Job Satisfaction, Integrity and Motivation on Performance. The International Journal Of Engineering And Science (IJES). Vol 5 Issue 1.

[5]. Bushra, F., Usman, A., and Naveed., A. (2011). Effect of Transformational Leadership on Employees' Job Satisfaction and Organizational Commitment in Banking Sector of Lahore (Pakistan). International Journal of Business and Social Science. Vol. 2 No. 18.

[6]. Darwito. (2008). Analisis Pengaruh Gaya Kepemimpinan Terhadap Kepuasan Kerja dan Komitmen Organisasi Untuk Meningkatkan Kinerja Karyawan (Studi Pada RSUD Kota Semarang). Tesis. Semarang: Universitas Diponegoro.

[7]. Davis, K. 2011. Perilaku Dalam Organisai. Jakarta: Erlangga.

[8]. Doll, W.J., Xia, W., and Torkzadeh, G. 1994. A Conformatory Factor Analysis of the end-user Computing Satisfaction Instrument. MIS Quarterly, 12(2): 159-174. 


\title{
International Advanced Research Journal in Science, Engineering and Technology
}

\author{
Vol. 5, Issue 9, September 2018
}

[9]. Epure, D.T., Ionescu, A., and Nancu, D. 2013. The Impact of Communication in Job Satisfaction: an Empirical Investigation within Romanian Companies. Economics and Applied Informatics. Issue 2.

[10]. Femi, A.F. 2014. The Impact of Communication on Workers' Performance in Selected Organisations in Lagos State, Nigeria. Journal Of Humanities And Social Science (IOSR-JHSS). Volume 19, Issue 8, Ver. II.

[11]. Goetsch., and Davis. 2013. Quality Management. Fourth Edition. Cram101 Incorporated.

[12]. Hair, J.F., Anderson, R.E., Tatham, R.L., and Black, W.C. 2008. Multivariate Data Analysis, Fifth Edition. USA: Prentice Hall International.

[13]. Hariandja, M.T.E. 2009. Manajemen Sumber Daya Manusia, Pengadaan, Pengembangan, Pengkompensasian, Peningkatan Produktivitas Pegawai. Jakarta: Grafindo.

[14]. Kreitner, R., and Kinicki, A. 2014. Organizational Behavioral. .Boston: McGraw-Hill.

[15]. Lalamentik, A.A., Kindangen, P., dan Lengkong, V. 2017. Pengaruh Gaya Kepemimpinan, Komunikasi dan Kompensasi terhadap Kinerja Karyawan pada Kantor Pelayanan Kekayaan Negara dan Lelang (KPKNL) Manado. Jurnal EMBA. Vol.5 No.1.

[16]. Mangkunegara, A.P. 2009. Manajemen Sumber Daya Manusia. Bandung: PT. Remaja Rosdakarya.

[17]. Masihabadi, A., Rajaei, A., Koloukhi, A.S., and Parsian, H. 2015. Effects of Stress on Auditors' Organizational Commitment, Job Satisfaction, and Job Performance. International Journal of Organizational Leadership. Vol 4.

[18]. Mitchell, T.R. 1978. People In Organization; Under Standing Their Behaviors. New York: Mc Grow-Hill.

[19]. Munandar, Smith, Kendall., dan Hulin. 2004. Prilaku dalam Organisasi. Edisi ke-7. Jilid 4. Cetakan ke-3. Jakarta: Penerbit Erlangga.

[20]. Naeem, S., and Khanzada, B. 2018. Role of Transformational Leadership in Employee's Performance with Mediating Role of Job Satisfaction in Health Sector of Pakistan. Journal of Health Education Research and Development. Vol 6 Issue 1.

[21]. Northouse, P. G. 2013. Kepemimpinan. Jakarta: PT Indeks.

[22]. Ostroff, C. 1992. The Relationship between Satisfaction,Attitude, and Perform- ance: An Organizational Level Analysis. Journal of Applied Psychology. Vol 77.

[23]. Pace R.W., dan Faules D.F. 2010, Komunikasi Organisasi: Strategi Meningkatkan Kinerja Perusahaan. Bandung: PT Remaja Rosdakarya.

[24]. Pandey, S.K. 2010. Cutback Management and the Paradox of Publiceness. Public Administration Review. $50(4)$ : 564 -71.

[25]. Paracha, M.U., Qamar, A., Mirza, A., Hassan, I., and Waqas, H. 2012. Impact of Leadership Style (Transformational \& Transactional Leadership) On Employee Performance \& Mediating Role ofJob Satisfaction” Study of Private School (Educator) In Pakistan. Global Journal of Management and Business Research. Vol 12 Issue 4.

[26]. Pradana, M.A., Sunuharyo, B.S., dan Hamid, D. 2013. Pengaruh Gaya Kepemimpinan Transformasional dan Transaksional terhadap Kinerja Karyawan. Jurnal Ekonomi Manajemen.

[27]. Rivai, V, Bachtiar., and Amar, B.R. 2014. Pemimpin Dan Kepemimpinan Dalam Organisasi. Jakarta: PT Raja Grafidno Persada.

[28]. Rivai, V., dan Sagala, E.J. 2013. Manajemen Sumber Daya Manusia untuk Perusahaan: Dari Teori ke Praktik. Edisi Kedua. Cetakan Kelima. Jakarta: PT. Rajagrafindo Persada.

[29]. Robbins, S.P., and Judge, T.A. 2013. Organizational Behavior Edition 15. New Jersey: Pearson Education.

[30]. Stoner, J.A.F. 2006. Management. Englewood Cliffs, N.J: Prentice Hall, Inc.

[31]. Subekti, A., and Setyadi, D. 2016. The Implication of Financial Compensation and Performance Appraisal System to Job Satisfaction And Motivation also Employee Performance In PT Pupuk Kalimantan Timur Indonesia. International Journal of Business and Management Invention. Vol 5 Issue 2.

[32]. Sugiyono. 2012. Metode Penelitian Kuantitatif, Kualitatif, dan R\&D. Bandung: Alfabeta.

[33]. Temitope, O.A., Oluwatomilola, A.E., Olanrewaju, O., and Airekun, A.O. 2016. Exploring the Relationship Between Communication and Employee Perfomance: A Study of Selected Private Organization and Public Corporation in Lagos State. International Journal of Social Sciences and Humanities Reviews. Vol.6 No.2.

[34]. Tourani, A., and Rast, S. 2012. Effect of Employees' Communication and Participation on Employees' Job Satisfaction: An Empirical Study on Airline Companies in Iran. International Conference on Economics, Trade and Development. Vol 36.

[35]. Wahidah, N. 2011. Pola Komunikasi Dalam Keluarga. Jurnal Musawa. Vol. 3 No. 2.

[36]. Yuseph, M. 2012. The Psychological Contract and Employee Perfomance in Post-Aquition Integration. Disertation. University of Pretorya Gordon Institute of Business Science. 